\title{
UPAYA PENERAPAN MODEL PEMBELAJARAN THINK PAIR SHARE DALAM MENINGKATKAN HASIL BELAJAR SISWA PADA MATA PELAJARAN PKn DI KELAS V SD NEGERI 055997 WONOGIRI
}

\author{
Rosdawati \\ Guru SD Negeri No. 055997 Wonogiri \\ Surel : rosdawati350@yahoo.com
}

\begin{abstract}
The Implementation With Think Pair Share Learning Model to Improving Student Outcomes Lesson In Civic Education In Class V SD Negeri No. 055997 Wonogiri Tahun Ajaran 2015/2016. This research aims to improve students' learning activities using Think Pair Share learning model in class V SD Negeri No. 055997 Wonogiri. These research subjects are 22 students. The study lasted for two cycles can be concluded that 1) The results of student learning through the implementation of the Think Pair Share learning model is based on observations of the two observers increased from the first cycle to the second cycle. 2) Activities of student learning through the implementation of the Think Pair Share learning model increases from the first cycle to the second cycle.
\end{abstract}

Keywords: Learning Think Pair Share, Student Outcomes

\begin{abstract}
Abstrak : Upaya Penerapan Model Pembelajaran Think Pair Share Dalam Meningkatkan Hasil Belajar Siswa Pada Mata Pelajaran PKn Di Kelas V SD Negeri 055997 Wonogiri Tahun Ajaran 2015/2016. Penelitian ini bertujuan untuk meningkatkan hasil belajar siswa dengan menggunakan model pembelajaran Think Pair Share di kelas V SD Negeri No. 055997 Wonogiri. Subjek penelitian ini berjumlah 22 orang siswa. Penelitian berlangsung selama dua siklus dapat disimpulkan bahwa 1) Hasil belajar siswa melalui penerapan model pembelajaran Think Pair Share berdasarkan pengamatan kedua pengamat mengalami peningkatan dari siklus I ke siklus II. 2) Aktivitas belajar siswa melalui penerapan model pembelajaran Think Pair Share meningkat dari siklus I ke siklus II.
\end{abstract}

Kata Kunci : Model pembelajaran Think Pair Share (TPS), Hasil Belajar

\section{PENDAHULUAN}

Kegiatan belajar mengajar di kelas dalam upaya melaksanakan pembelajaran berorientasi afektif terus dilakukan peneliti sebagai guru PKn di SD Negeri 055997 Wonogiri. Dalam pembelajaran PKn khususnya, pengalaman guru sebagai peneliti bahwa siswa sering ribut ketika guru menyampaikan pelajaran. Hal ini menandakan bahwa afektif siswa masih rendah dimana sehingga mengakibatkan hasil belajar PKn siswa rendah.

Pembelajaran yang berpusat pada siswa lebih menitikberatkan siswa aktif belajar mengembangkan kemampuan berpikirnya. Yakni pembelajaran yang membantu siswa menempatkan diri dalam situasi di mana mereka mampu melakukan konstruksikonstruksi pemikirannya dalam situasi wajar, alami dan mampu mengekspresikan dirinya secara tepat dalam hal perubahan sikap yang lebih baik. Hal ini berarti pembelajaran seharusnya melatih keterampilan berpikir siswa dalam menghimpun suatu konsep dan guru seharusnya memfasilitasi hal tersebut dengan menciptakan situasi pembelajaran yang melatih keterampilan berpikir tersebut yang berkaitan dengan peningkatan afektif siswa.

Peneliti telah mengajar kurang lebih 30 tahun. Berdasarkan pengalaman mengajar masalah yang dihadapi dalam 
Jurnal Guru Kita (JGK). Vol 1 (2) Maret 2017, hlm. 19-25

mengajar adalah kurangnya afektif siswa selama proses pembelajaran, terkhusus pada kelas V SD Negeri 055997 Wonogiri T.A. 2015/2016. Suasana pada kelas ini sangat tidak kondusif selama peneliti mengajar sehingga berujung pada terganggunya siswa lain yang sedang serius belajar, selain itu siswa jarang sekali bertanya padahal guru telah berusaha memancing para siswa untuk bertanya. Kesulitan peneliti dalam meningkatkan afektif siswa menjadi motivasi untuk melakukan Penelitian Tindakan Kelas.

Tanggung jawab dalam kegiatan belajar mengajar juga menunjukkan masih rendah, hal ini bisa dibuktikan dengan dari 22 siswa kelas $\mathrm{V}$ yang diberikan tugas di sekolah maupun disekolah, hanya 10 (26\%) orang siswa saja yang mengumpulkan tugas. Selain itu siswa telah menjadikan kebiasaan mengerjakan tugas asal-asalan dan kurang teliti menjadikan siswa tidak serius untuk memahami pelajaran. Padahal melalui tugas yang diberikan dan dikerjakan dengan teliti siswa akan lebih terlatih dan memahami setiap materi yang diajarkan.

Melihat permasalahanpermasalahan yang muncul diatas, perlu adanya model pembelajaran yang mampu mengatasi masalah yang muncul secara kooperatif. Salah satu model pembelajaran yang memadai dan mampu menyelesaikan masalah adalah model pembelajaran kooperatif Think Pair Share atau yang biasa disebut dengan TPS. Model yang dikembangkan oleh Spencer Kangan dan Frank Lyman merupakan jenis pembelajaran kooperatif yang dirancang untuk mempengaruhi pola interaksi siswa. Guru menciptakan interaksi yang mendorong rasa ingin tahu, ingin mencoba, bersikap mandiri dan ingin maju. Guru memberikan suatu informasi yang mendasar saja sebagai dasar pemikiran bagi anak didik dalam mencari dan menemukan sendiri informasi lainnya.

Dari uraian latar belakang, maka penulis dapat merumuskan permasalahan yang akan dijawab yaitu 1) Bagaimana afektif belajar siswa dengan menerapkan model pembelajaran kooperatif tipe Think Pair Share pada materi pokok peraturan Menghargai Keputusan Bersama.di kelas V semester genap SD Negeri 055997 Wonogiri Tahun Ajaran 2015/2016; 2) Bagaimana hasil belajar siswa dengan menerapkan model pembelajaran kooperatif tipe Think Pair Share pada materi pokok Menghargai Keputusan Bersama di kelas V semester genap SD Negeri 055997 Wonogiri Tahun Ajaran 2015/2016?; Sehingga berdasarkan rumusan masalah tersebut, penelitian ini bertujuan untuk ; 1) Untuk mengetahui afektif belajar siswa dengan menerapkan model pembelajaran kooperatif tipe Think Pair Share pada materi pokok Menghargai Keputusan Bersama di kelas V semester genap SD Negeri 055997 Wonogiri Tahun Ajaran 2015/2016; 2) Untuk mengetahui hasil belajar siswa dengan menerapkan model pembelajaran kooperatif tipe Think Pair Share pada materi pokok Menghargai Keputusan Bersama di kelas V semester genap SD Negeri 055997 Wonogiri Tahun Ajaran 2015/2016;. Model pembelajaran kooperatif tipe TPS (Think-pair-Share) atau berpikir-berpasangan-berbagi yang dikembangkan oleh Spencer Kangan dan Frank Lyman merupakan jenis pembelajaran kooperatif yang dirancang untuk mempengaruhi pola interaksi siswa. 


\section{METODE}

Tempat penelitian adalah tempat yang digunakan dalam melakukan penelitian untuk memperoleh data yang diinginkan. Atas kesediaan semua pihak yang terkait, penelitian ini dilakukan di SD Negeri 055997 Wonogiri yang beralamat di Jalan Tanjung Pura.

Waktu penelitian adalah waktu berlangsungnya penelitian atau saat penelitian ini dilangsungkan. Penelitian ini dilaksanakan pada semester genap Tahun Ajaran 2015/2016 selama 4 (empat) bulan mulai dari bulan Februari 2016 sampai dengan Juni 2016. Pengambilan data dilaksanakan pada bulan April selama 4 (empat) KBM yang dibagi dalam 2 (dua) siklus.

Subyek penelitian adalah siswasiswi kelas V SD Negeri 055997 Wonogiri Tahun Ajaran 2015/2016 yang berjumlah 22 siswa.

Penelitian ini menggunakan Penelitian Tindakan Kelas (PTK). Menurut Tim Pelatih Proyek PGSM, PTK adalah suatu bentuk kajian yang bersifat reflektif oleh pelaku tindakan yang dilakukan untuk meningkatkan kemantapan rasional dari tindakan mereka dalam melaksanakan tugas, memperdalam pemahaman terhadap tindakan-tindakan yang dilakukan itu, serta memperbaiki kondisi dimana praktek pembelajaran tersebut dilakukan (dalam Mukhlis, 2000).

Sesuai dengan jenis penelitian yang dipilih, yaitu penelitian tindakan, maka penelitian ini menggunakan model penelitian tindakan dari Kemmis dan Taggart, yaitu berbentuk spiral dari siklus yang satu ke siklus yang berikutnya. Setiap siklus meliputi planning (rencana), action (tindakan), observation (pengamatan), dan reflection (refleksi). Langkah pada siklus berikutnya adalah perencanaan yang sudah direvisi, tindakan, pengamatan, dan refleksi. Sebelum masuk pada siklus 1 dilakukan tindakan pendahuluan yang berupa identifikasi permasalahan. Prosedur tersebut banyak diacu oleh guru dalam melaksanakan PTK dengan memuat bagan dalam Sani dan Sudiran (2012).

Penelitian ini berbentuk Penelitian Tindakan Kelas (PTK). PTK pertama kali diperkenalkanoleh psikologi sosial Amerika yang bernama Kurt Lewin pada tahun 1946 (Aqib, 2006 :13). Menurut Lewin dalam Aqib (2006 : 21) menyatakan bahwa dalam satu Siklus terdiri atas empat langkah, yaitu perencanaan (planning), tindakan (acting), observasi (observing) dan refleksi (reflecting).

Metode Analisis Data pada penelitian ini digunakan metode deskriptif dengan membandingkan hasil belajar siswa sebelum tindakan dengan hasil belajar siswa setelah tindakan.

Penelitian menggunakan indikator ketercapaian yakni KKM PKn untuk kelas V di SD Negeri No. 055997 Wonogiri sebesar 70 untuk individu siswa. Artinya siswa dikatakan tuntas belajar jika nilainya dalam formatif mencapai KKM ini. Sedangkan kelas dikatakan tuntas atau penelitian berhasil jika paling tidak $85 \%$ dari jumlah siswa dalam kelas subjek memperoleh nilai mencapai KKM.

\section{PEMBAHASAN}

Untuk mengetahui kemampuan awal siswa dilakukan dengan tes kemampuan awal sebelum penerapan Model pembelajaran TPS. Tes kemampuan awal (tes kognitif) bertujuan untuk mengetahui seberapa besar kemampuan awal yang dimiliki siswa dalam memahami materi pada mata pelajaran PKn. Hasil tes 
kemampuan awal menunjukan rendahnya penguasaan materi siswa kelas V SD Negeri No. 055997 Wonogiri.

Diakhir pertemuan 2 diadakan tes formatif 1 untuk melihat hasil belajar siswa. Hasil belajar yang diperoleh pada Siklus I selama dua pertemuan disajikan dalam Tabel.

Tabel Distribusi Data Postes 1

\begin{tabular}{|c|c|c|}
\hline Nilai & Frekuensi & Rata-Rata \\
\hline 60 & 8 & \\
\cline { 1 - 2 } 80 & 6 & \multirow{2}{*}{80} \\
\hline 100 & 8 & \\
\cline { 1 - 2 } Jumlah & 22 & \\
\hline
\end{tabular}

Berdasarkan tabel bahwa hanya 14 orang tuntas dari KKM, sehingga siklus I belum berhasil memberikan ketuntasan hasil belajar kognitif siswa.

Pada setiap pembelajaran pertemuan 1 dan pertemuan 2 pada silus I, ketika peneliti melakukan proses pembelajaran peneliti berkolaborasi dengan satu orang pengamat (observer) untuk mengamati bagaimana afektif dan psikomotorik siswa. Pengamat mengamati aktivitas siswa sesuai dengan lembar pengamatan yang sebelumnya telah disiapkan oleh peneliti. Persentase pengamatan hasil aktivitas siswa pada pertemuan 1 dan pertemuan 2 ini adalah seperti pada tabel berikut :

\section{Tabel Hasil belajar aktivitas siswa} siklus I

\begin{tabular}{|c|l|c|c|}
\hline No & Psikomotorik & Skor & Proporsi \\
\hline 1 & $\begin{array}{l}\text { Menulis/ } \\
\text { membaca }\end{array}$ & 24.25 & $44 \%$ \\
\hline 2 & $\begin{array}{l}\text { Mengerjakan } \\
\text { LKS }\end{array}$ & 13.75 & $25 \%$ \\
\hline 3 & $\begin{array}{l}\text { Bertanya pada } \\
\text { teman }\end{array}$ & 3.5 & $6 \%$ \\
\hline 4 & Bertanya pada & 3.75 & $7 \%$ \\
\hline
\end{tabular}

\begin{tabular}{|c|c|c|c|} 
& guru & & \\
\hline 5 & $\begin{array}{l}\text { Yang tidak } \\
\text { relevan } \\
\text { dengan KBM }\end{array}$ & 9.75 & $18 \%$ \\
\hline & Jumlah & 55 & $100 \%$ \\
\hline
\end{tabular}

Dalam pelaksanaan kegiatan belajar mengajar diperoleh informasi dari hasil pengamatan sebagai berikut :

a. Guru kurang terampil dalam pengolahan pembelajaran dengan menerapkan model pembelajaran TPS. Hal ini dilihat dari kurangnya guru dalam apersepsi, pada KBM 1 guru tidak memberikan penjelasan materi melainkan langsung memberikan pertayaan pada siswa, dan pada KBM 2 tidak dilakukan penarikan kesimpulan.

b. Siswa kurang antusias dalam diskusi, hal ini mungkin dikarenakan pertanyaan dalam LKS yang diberikan guru kurang menantang atau menurut siswa kurang menarik. Sehingga siswa tidak serius dalam diskusi untuk memecahkan masalah.

c. Guru kurang terampil dalam mengolah waktu, sehingga setiap tahap belajar dengan menerapkan model pembelajaran TPS terkesan dilakukan tanpa persiapan dan terburu-buru.

d. Hasil belajar siswa belum mencapai target kelulusan yakni $85 \%$ siswa lulus KKM yang ditentukan. Memang terjadi peningkatan hasil belajar siswa ke siklus I, akan tetapi hal ini menunjukkan bahwa perlu adanya perbaikan.

e. Aktivitas belajar siswa belum sesuai dengan yang diharapkan, karena aktivitas menulis, membaca persentasenya hanya $44 \%$, yang disusul dengan aktivitas mengerjakan LKS sebesar 25\%, 
aktivitas bertanya pada teman $6 \%$, bertanya pada guru $7 \%$ dan aktivitas yang tidak relevan dengan KBM sebesar 18\%. Tingginya aktivitas menulis dan membaca mengindikasikan siswa tidak mempersiapkan diri maupun tidak menguasai materi ajar, sedangkan aktivitas yang tidak relevan dengan KBM mengindikasikan siswa kurang serius dalam pembelajaran.

Berdasarkan refleksi pada pembelajaran pertemuan 1 dan pertemuan 2, dan analisis hasil belajar siklus I maka perlu ada perbaikan pembelajaran berikutnya pada siklus II.

Setelah melakukan beberapa tindakan perbaikan pembelajaran pada Siklus II maka dilakukan tes pada Siklus II sebagai Postes II. Data Postes II disajikan dalam Tabel.

Tabel Distribusi Data Postes II

\begin{tabular}{|c|c|c|}
\hline Nilai & Frekuensi & Rata-rata \\
\hline 60 & 2 & \\
\cline { 1 - 2 } 80 & 5 & \multirow{2}{*}{91.81} \\
\cline { 1 - 2 } 100 & 15 & \\
\cline { 1 - 2 } Jumlah & 22 & \\
\hline
\end{tabular}

Merujuk pada Tabel, nilai terendah untuk Postes II adalah 60 dan tertinggi adalah 100 dan 2 orang nilai dibawah kriteria ketuntasan. Nilai ini berada di atas kriteria keberhasilan sehingga dapat dikatakan KBM Siklus II telah berhasil memberi ketuntasan belajar pada siswa dalam kelas. Nilai rata-rata kelas adalah 91.81 ketuntasan belajar siswa $91 \%$, karena ketuntasan belajar siswa $87,8 \quad(>85 \%)$ maka penelitian ini dikatakan berhasil.

Pada setiap pembelajaran pertemuan 3 dan pertemuan 4 pada siklus II, ketika peneliti melakukan proses pembelajaran peneliti berkolaborasi dengan satu orang pengamat (observer) untuk mengamati aktivitas siswa. Pengamat mengamati aktivitas siswa sesuai dengan lembar pengamatan yang sebelumnya telah disiapkan oleh peneliti. Pengamatan hasil belajar aktivitas menurut observer pada pertemuan 3 pertemuan 4 ini adalah seperti pada tabel.

Tabel Hasil belajar aktivitas siswa pada siklus II

\begin{tabular}{|c|c|c|c|}
\hline No & Psikomotorik & Skor & Proporsi \\
\hline 1 & $\begin{array}{l}\text { Menulis/ } \\
\text { membaca }\end{array}$ & 16 & $29 \%$ \\
\hline 2 & $\begin{array}{l}\text { Mengerjakan } \\
\text { LKS }\end{array}$ & 25.25 & $46 \%$ \\
\hline 3 & $\begin{array}{l}\text { Bertanya pada } \\
\text { teman }\end{array}$ & 8.75 & $16 \%$ \\
\hline 4 & $\begin{array}{l}\text { Bertanya pada } \\
\text { guru }\end{array}$ & 4.75 & $9 \%$ \\
\hline 5 & $\begin{array}{l}\text { Yang tidak } \\
\text { relevan } \\
\text { dengan KBM }\end{array}$ & 0.25 & $0 \%$ \\
\hline \multicolumn{2}{|r|}{ Jumlah } & 55 & $100 \%$ \\
\hline
\end{tabular}

Pada tahap ini akan dikaji apa yang telah terlaksana dengan baik maupun yang masih kurang baik dalam proses belajar mengajar dengan penerapan model pembelajaran TPS. Dari data-data yang telah diperoleh dapat diuraikan sebagai berikut :

1. Kekurangan siklus I sudah diperbaiki di siklus II. Semua tahapan penerapan model pembelajaran TPS sudah dilakukan dengan baik oleh guru.

2. Siswa sudah lebih terampil dalam menyelesaikan soal PKn dibuktikan dengan meningkatnya hasil belajar siswa. Pada siklus II semua siswa sudah tuntas $91 \%$ secara klasikal dengan rata-rata nilai siswa yakni 91,81 . 
3. Rata-rata aktivitas belajar siswa sudah menunjukan peningkatan dimana siswa lebih aktif dalam mengerjakan LKS (46\%) dan menyusutnya aktivitas yang tidak relevan dengan KBM menjadi $0 \%$.

4. Karena target ketuntasan yang menjadi acuan dalam penelitian sudah tercapai maka penelitian ini dihentikan hanya dengan melakukan dua siklus saja.

Berdasarkan data hasil

penelitian di atas, dapat dilihat bahwa terjadi peningkatan hasil belajar maupun aktivitas siswa dalam menyelesaikan soal PKn dimana meningkatnya hasil belajar siswa. Pada setiap tahap refleksi dilihat terjadi peningkatan tiap siklusnya. Pada siklus I rata-rata aktivitas belajar siswa yakni menulis, membaca $44 \%$ turun menjadi $29 \%$ pada siklus II. Memang aktivitas menulis, membaca ini diharapkan persentasenya lebih kecil dibanding mengerjakan LKS karena hal yang diinginkan adalah siswa lebih banyak mengerjakan LKS, bukannya menulis, membaca. Persentase mengerjakan LKS $25 \%$ pada siklus I meningkat menjadi $46 \%$ pada siklus II. Hal ini menunjukkan bahwa aktivitas siswa sudah baik dan aktif dalam mengerjakan tugas yang diberikan oleh guru. Aktivitas bertanya pada teman mengalami peningkatan dari $6 \%$ menjadi $16 \%$ pada siklus II. Aktivitas bertanya pada teman mengalami peningkatan yang mengindikasikan siswa saling membantu satu sama lain, dan sama-sama belajar. Hal ini menunjukkan siswa mulai aktif berdiskusi dengan baik dan kooperatif siswa meningkat. Aktivitas bertanya pada guru juga mengalami peningkatan dari $7 \%$ menjadi $9 \%$, yang menunjukkan siswa sudah mulai aktif dalam berkomunikasi dengan guru.
Kemampuan siswa dalam memahami materi PKn juga mengalami peningkatan dimana pada uji pretes tidak ada siswa yang mendapat nilai di atas KKM, rata-rata nilai kelas yakni 50,45 . Siswa lulus pada formatif I hanya 14 orang dengan ketuntasan klasikal hanya $63 \%$ dengan rata-rata nilai kelas yakni 80 dan di siklus II dengan ratarata kelas 91,81 dengan ketuntasan klasikal mencapai $91 \%$.

Peningkatan hasil belajar ini menunjukkan bahwa model pembelajaran TPS dapat meningkatkan hasil belajar PKn siswa. Dengan menggunakan model pembelajaran TPS ini, siswa menjadi lebih mampu dalam menyelesaikan soal PKn karena siswa diajak untuk melihat contoh langsung dalam kehidupan sehari-hari, sehingga aktivitas belajar siswa meningkat. Peningkatan aktivitas siswa ini sejalan dengan meningkatnya hasil belajar siswa.

Dengan demikian secara keseluruhan dapat dikatakan bahwa proses pembelajaran menerapkan LKS melalui model pembelajaran kooperatif tipe TPS pada pembelajaran PKN kelas V SD Negeri 055997 Wonogiri berhasil memberi ketuntasan klasikal sampai pada akhir siklus II. Keadaan tersebut dapat dijadikan sebagai kajian bahwa dengan siklus yang berulang dan menerapkan LKS melalui model pembelajaran kooperatif tipe TPS memungkinkan meningkatkan ketuntasan pembelajaran PKN siswa. Meski ketuntasan klasikal tidak mencapai $100 \%$ namun penelitian hanya melaksanakan sampai pada dua siklus karena keterbatasan-keterbatasan dalam penelitian ini, diantaranya:

1. Karena waktu yang dilakukan peneliti untuk melakukan penelitian hanya terbatas pada materi 
peraturan perundang-undangan tingkat pusat dan daerah.

2. Keterbatasan tenaga dan biaya yang dimiliki peneliti membuat penelitian hanya dilakukan pada satu kelas saja.

Berdasarkan analisis data dan pembahasan, maka dapat disimpulkan hasil penelitian di kelas V SD Negeri 055997 Wonogiri Tahun Ajaran 2015/2016 bahwa :

1. Data aktivitas siswa menurut pengamatan pada siklus I antara lain menulis membaca (44\%), mengerjakan LKS (25\%), bertanya pada teman $(6 \%)$, bertanya pada guru $(7 \%)$, dan yang tidak relevan dengan KBM (18\%). Sedangkan data aktivitas siswa menurut pengamatan pada siklus II antara lain menulis membaca (29\%), mengerjakan LKS (46\%), bertanya pada teman $(16 \%)$, bertanya pada guru (9\%), dan yang tidak relevan dengan KBM (0\%). Dengan demikian terjadi peningkatan aktivitas belajar siswa melalui penerapan model pembelajaran kooperatif tipe TPS pada mata pelajaran PKn di kelas V SD Negeri 055997 Wonogiri T.P. 2015/2016.

2. Hasil penelitian menunjukkan bahwa penerapan melalui model pembelajaran kooperatif tipe TPS dapat meningkatkan penguasaan kompetensi PKn siswa, terbukti dari hasil tes siswa ketuntasan pembelajaran naik. Pada siklus I rata-rata nilai tes 80 dengan ketuntasan pembelajaran sebesar $63 \%$ dan pada siklus II rata-rata nilai tes 91,81 dengan ketuntasan pembelajaran naik menjadi $91 \%$, dan berhasil memberikan ketuntasan hasil belajar secara klasikal

\section{DAFTAR RUJUKAN}

Anita, Lie. 2000. Cooperatif Learning. Jakarta. Alfabeta: Grafindo.

Aqib, Zainal. 2014. Model-Model, Media, dan Strategi Pembelajaran Kontekstual (Inovatif. Bandung: Yrama Widya.

Ibrahim, Muhsin dkk. 2000. Pembelajaran Kooperatif. Surabaya: University Press.

Mukhlis, Abdul. (Ed). 2000. Penelitian Tindakan Kelas.Makalah Panitian Pelatihan Penulisan Karya Ilmiah untuk Guru-guru se-kabupaten Tuban. 